\title{
Detection and attribution of Lake Victoria's water-level fluctuations in a changing climate
}

\section{Obed M. Ogega ${ }^{a}$, James Mbugua ${ }^{b}$, Herbert O. Misianic ${ }^{c}$ Maurice Nyadawa ${ }^{d}$, Enrico Scoccimarro ${ }^{\mathrm{e}}$, and Hussen S. Endris ${ }^{\mathrm{c}}$}

\author{
aProgrammes, The African Academy of Sciences, Nairobi, Kenya \\ ${ }^{\mathrm{b}}$ Coastal Oceans Research and Development - Indian Ocean (CORDIO) East Africa, Mombasa, \\ Kenya \\ 'IGAD Climate Prediction and Applications Centre, Nairobi, Kenya \\ ${ }^{\mathrm{d} S c h o o l ~ o f ~ E n g i n e e r i n g ~ a n d ~ T e c h n o l o g y, ~ J a r a m o g i ~ O g i n g a ~ O d i n g a ~ U n i v e r s i t y ~ o f ~ S c i e n c e ~ a n d ~}$ \\ Technology, Kisumu, Kenya \\ ${ }^{\mathrm{e}}$ Fondazione Centro Euro-Mediterraneo sui Cambiamenti Climatici, 40127 Bologna, Italy
}

Corresponding author: obed.matundura@gmail.com (O. Ogega)

\section{Abstract}

This study investigated the influence of land-use and precipitation change and variability on Lake Victoria's water-level fluctuations. Extreme precipitation events, corresponding to extreme waterlevels, over the lake and its catchment area were identified and their return periods estimated by fitting them into a generalized extreme value (GEV) distribution. Using general circulation models from the $6^{\text {th }}$ phase of the Coupled Model Intercomparison Project (CMIP6)'s Detection \& Attribution Model Intercomparison Project (DAMIP), an assessment of the potential contribution of human-induced climate change on the observed precipitation patterns over the study area was done. The greatest precipitation anomalies for the period 1900-2020 were recorded in 1961's October-December (OND) season and 2019's June-August (JJA) and OND seasons, corresponding to the period when the highest water-levels were recorded in Lake Victoria. While land-use change in the study domain was observed, extended and unusually heavy June to December 2019 precipitation bore the greatest responsibility for the 2019/2020 high water-levels in Lake Victoria. The OND precipitation event of 2019 was a 1-in-52-year event compared to the 1961 's 1-in-693 years. Differences in return periods at various parts of the lake imply a high spatial climate variability within the lake itself. An analysis of the fraction of attributable risk (FAR) showed natural variability to have a greater influence on the JJA and OND precipitation patterns over Lake Victoria than human-induced climate change. However, variability over the land area of the study domain was mainly driven by human-induced climate change rather than natural variability, implying a unique climate system over Lake Victoria. Findings from the current study enhance the understanding of Lake Victoria's water budget and motivate for further research to inform effective strategies on the planning and use of Lake Victoria's water resources in a changing climate.

\section{Keywords}

Lake Victoria; Climate change; Return periods; Detection and Attribution; DAMIP; CMIP6 


\section{Introduction}

Occupying an approximate area of $69,000 \mathrm{~km}^{2}$, Lake Victoria is the largest and second largest freshwater lake in Africa and the world, respectively (UNEP, 2006). The lake is the largest inland fishery in the world supporting over 40 million inhabitants; about three million of which draw their livelihoods from the lake's fisheries (e.g., Njiru et al., 2008; World Bank Group, 2016). Additionally, the lake indirectly supports about 340 million inhabitants of the Nile River Basin given that it is the source of the White Nile River (Sutcliffe \& Parks, 1999); one of the main tributaries of the Nile.

Approximately $80 \%$ of the water in Lake Victoria comes from direct precipitation while the rest $(20 \%)$ is obtained from river inflows (Sutcliffe \& Petersen, 2007). Due to its large spatial extent and remarkable topographical gradients, Lake Victoria has an influence on, and is also influenced by, East Africa's climate (Awange et al., 2013). The Lake Victoria Basin (LVB), the lake's catchment area, experiences significant climate variability over time and space (Faramarzi et al., 2013; Ogega, Koske, et al., 2020; Stager et al., 2007). Hence, any changes in climate are likely to disturb the lake's water balance, potentially resulting in a socio-economic ripple effect in the LVB and the entire Nile River Basin (NRB). On one hand, water surplus over the lake may cause more intense and frequent flooding in the lake basin's lowlands, potentially destroying life and livelihoods. On the other hand, a water deficit (e.g., Awange et al., 2008; Swenson \& Wahr, 2009) may diminish water availability for domestic and industrial use for countries in the LVB and NRB, such as Egypt and Sudan, that almost entirely depend on the Nile - one of whose main sources is Lake Victoria - for their freshwater needs (Di Baldassarre et al., 2011; Vanderkelen et al., 2018b). Hence, concerted effort is required to enhance the understanding of the lake's water balance and inform strategies for management of the socio-economic implications of the water-level fluctuations on all the 11 countries in the NRB (Kiwanuka-Tondo et al., 2019; Olaka et al., 2019; Vanderkelen et al., 2018b).

While efforts have been dispensed towards understanding Lake Victoria's water balance, the skill of quantification of lake inflow, outflow, and evaporation remains limited (Shamsudduha et al., 2017; Vanderkelen et al., 2018a). Hitherto, most of the research work has focused on the East Africa scale, resulting in minimal literature on the spatio-temporal precipitation characteristics over the lake and its basin. Yet, the lake provides a major environmental (Anyah et al., 2006) and socio-economic support (Awange et al., 2013; World Bank Group, 2016) to East Africa.

Hardly any extreme precipitation event attribution studies exist for East Africa - even fewer for in the LVB. One of the reasons for this could be the unavailability of adequate observational data, especially over the lake, for use in model validation and bias correction (Otto et al., 2015; Washington et al., 2006). A study by Marthews et al. (2019) concluded that human-induced climate change had resulted in less precipitation during the March-May (MAM) season over Lake Victoria. In contrast, a similar study by Uhe et al. (2018) found no significant influence of climate change on precipitation in Kenya. The current study advances earlier works by focusing on the LVB and using model simulations from the state-of-the-art Detection and Attribution Model Intercomparison Project (DAMIP; Gillett et al., 2016). DAMIP is one of the projects under the $6^{\text {th }}$ phase of the Coupled Model Intercomparison Project (CMIP6; Eyring et al., 2016).

In late 2019 and early 2020, unprecedented high water-levels were recorded in Lake Victoria resulting in considerable flooding in the lake-adjacent areas in Kenya, Uganda, and Tanzania 
(Mafaranga, 2020; Nile Basin Initiative, 2020; Ram, 2020). The last time such high water-levels were observed was between 1961 and 1964, caused by unusually heavy rains in the LVB at the time (Awange et al., 2008; Kite, 1981). The current study investigated the lake's high water-levels of 2019 by assessing the relationship between patterns of the lake's historical water-levels, precipitation, and land-cover. Additionally, the study estimated return period for the 2019 precipitation event, and whether the event was triggered by human-induced climate change or natural variability. The rest of the paper is structured into Material and methods (2), Results and discussion (3), and Conclusion and recommendations (4).

\section{Material and methods}

\subsection{Study area}

Lake Victoria straddles the equator and is shared among three East African countries namely Kenya, Uganda, and Tanzania (Figure 1). The lake's catchment area consists of a network of 23 rivers in five countries namely Kenya, Uganda, Tanzania, Burundi, and Rwanda. The White Nile River is the lake's only outflow and forms part of the greater Nile River (Senay et al., 2014; Sutcliffe, 2009). The lake is located at $1,135 \mathrm{~m}$ above mean sea level with its main rainy seasons being MAM and October-December (OND). July-August (JJA) is the region's "dry" season (Awange et al., 2013; Yang et al., 2015). 


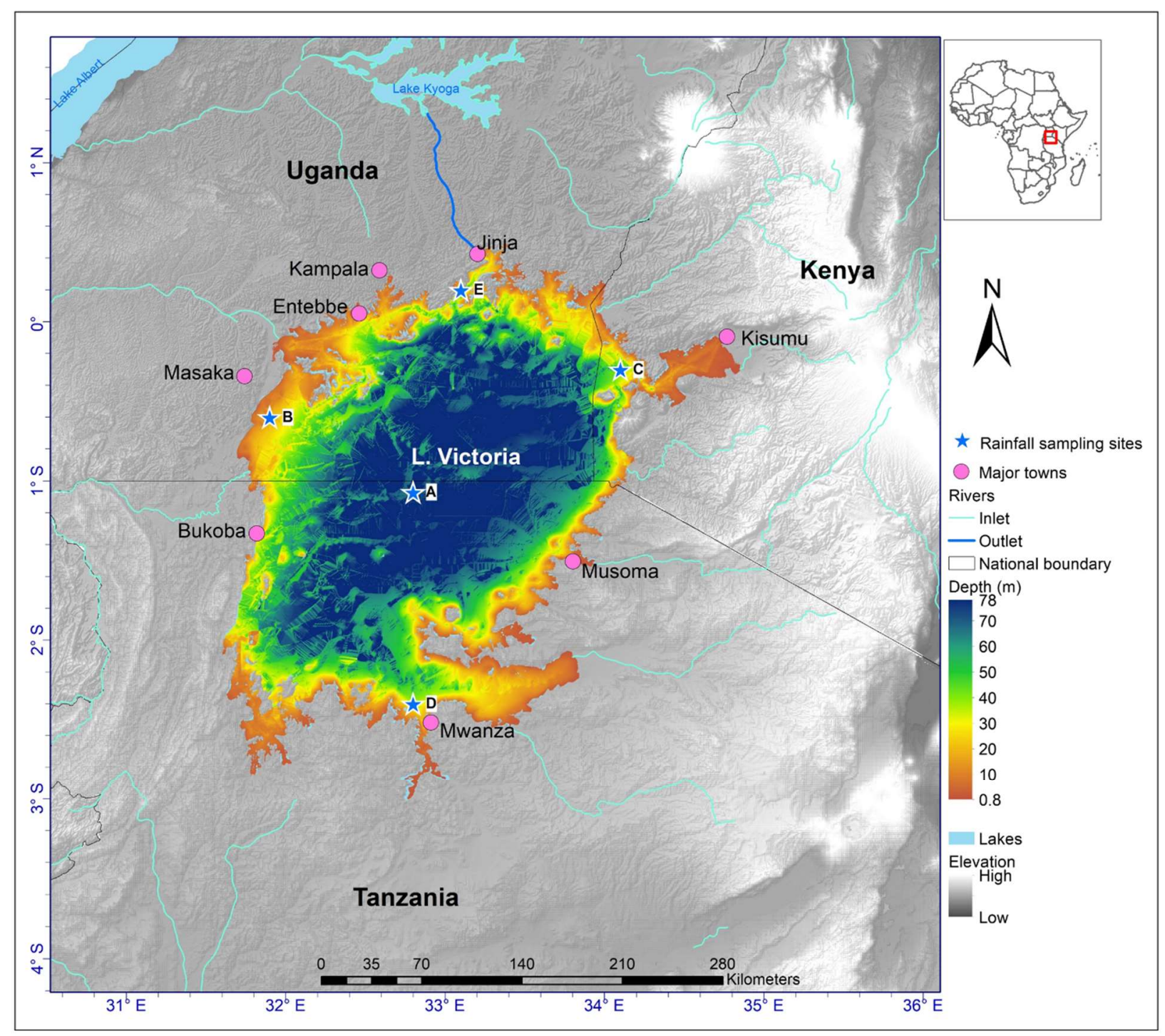

Figure 1. A topographic map of the study domain

The map (Figure 1) was produced using bathymetry data from the Harvard Dataverse (Hamilton et al., 2016), river shapefiles from Food and Agriculture Organization (FAO) geonetwork portal (http://bit.ly/3bkW1Ky), and urban data digitized from google earth and basemap from United States Geological Survey. Areas marked A, B, C, D, and E were used in the study to represent the Centre, West, East, South, and North of the lake, respectively.

\subsection{Data}

The current study used daily and monthly precipitation datasets from the Climate Hazards Group InfraRed Precipitation with Station data (CHIRPS). CHIRPS is a quasi-global precipitation dataset available from 1981 to near present, incorporating climatology, in-situ station data, and satellite imagery to form a gridded precipitation time series at $0.05^{\circ}$ horizontal resolution (Funk, Peterson, et al., 2015). The datasets have been validated (Dinku et al., 2018) and used widely for studies in East Africa (e.g., Gebrechorkos, 2019; Geleta \& Deressa, 2021; Ngoma et al., 2021; Ogega et al., 2020) and beyond (e.g., Bai et al., 2018; Ogega et al., 2020a). Additionally, Centennial Trends 
Greater Horn of Africa precipitation dataset (CenTrends) data were used with CHIRPS to provide a long time series (1900-2020). CenTrends data provides a reasonably accurate and complete set of gridded seasonal precipitation products spanning the Greater Horn of Africa region $\left(15^{\circ} \mathrm{S}-18\right.$ ${ }^{\circ} \mathrm{N}, 28^{\circ} \mathrm{E}-54^{\circ} \mathrm{E}$ ) for the period 1900 to 2014 , at $0.1^{\circ}$ horizontal resolution (Funk et al., 2015a) (Funk et al., 2015a). Here, CHIRPS data (monthly totals) were extended from 1981 to 1900 using CenTrends data as in Uhe et al. (2018).

Table 1 provides details of DAMIP model simulations used in the current study for extreme event detection and attribution. CMIP6 general circulation model (GCM) simulations provide the most advanced model simulations to enhance the understanding of the earth system's response to forcing, origins and consequences of systematic model biases, and the assessment of future climate changes considering internal climate variability, predictability, and uncertainties in scenarios (Eyring et al., 2016). DAMIP model simulations enable improved estimation of natural and anthropogenic forcing contributions to observed changes in regional and global warming and in other climate variables (Gillett et al., 2016).

Table 1. Details of the DAMIP GCM simulations used in the study, at a nominal resolution of $100 \mathrm{~km}$ and at a monthly temporal resolution. All simulations are part of the historical experiment with data for both natural forcing (hist-nat) and greenhouse gas emissions (hist-GHG), available at https:/lesgf-node.llnl.gov/search/cmip6/

\begin{tabular}{|c|c|c|c|}
\hline Model name & Institution & Variant label (s) & Reference \\
\hline $\begin{array}{l}\text { Community Earth } \\
\text { System Model } \\
\text { Version } 2 \text { (CESM2) }\end{array}$ & $\begin{array}{l}\text { The National Center } \\
\text { for Atmospheric } \\
\text { Research (NCAR), } \\
\text { USA }\end{array}$ & $\begin{array}{l}\text { r1ilp1f1, r2ilp1f1, } \\
\text { and r3ilp1f1 }\end{array}$ & $\begin{array}{l}\text { Danabasoglu et al. } \\
\text { (2020) }\end{array}$ \\
\hline $\begin{array}{l}\text { Meteorological } \\
\text { Research Institute } \\
\text { Earth System Model } \\
\text { version } 2 \text { (MRI- } \\
\text { ESM2-0) }\end{array}$ & $\begin{array}{l}\text { Meteorological } \\
\text { Research Institute } \\
\text { (MRI), Japan }\end{array}$ & $\begin{array}{l}\text { r1ilp1f1, r2i1p1f1, } \\
\text { r3ilp1f1, and } \\
\text { r5ilp1f1 }\end{array}$ & Kawai et al. (2019) \\
\hline $\begin{array}{l}\text { Beijing Climate } \\
\text { Center Climate } \\
\text { System Model (BCC- } \\
\text { CSM2-MR) }\end{array}$ & $\begin{array}{l}\text { Beijing Climate } \\
\text { Center (BCC), China }\end{array}$ & $\begin{array}{l}\text { r2ilp1f1 and } \\
\text { r3ilp1f1 }\end{array}$ & Wu et al. (2019) \\
\hline $\begin{array}{l}\text { Geophysical Fluid } \\
\text { Dynamics Laboratory } \\
\text { Earth System Model } \\
\text { version } 4.1 \text { (GFDL- } \\
\text { ESM4) }\end{array}$ & $\begin{array}{l}\text { GFDL, U.S. National } \\
\text { Oceanic \& } \\
\text { Atmospheric } \\
\text { Administration } \\
\text { (NOAA), USA }\end{array}$ & rlilp1f1 & Dunne et al. (2020) \\
\hline
\end{tabular}

A summary of other datasets used in our study is provided in 
Table 2. 
Table 2. Details of other datasets used in the study

\begin{tabular}{|l|l|l|}
\hline Variable & Dataset & Description \\
\hline $\begin{array}{l}\text { Lake water- } \\
\text { level }\end{array}$ & $\begin{array}{l}\text { Copernicus } \\
\text { Global Land } \\
\text { Operations }- \\
\text { Lot 2 } \\
\text { (CGLOPS2) }\end{array}$ & $\begin{array}{l}\text { CGLOPS2 contains lake water-levels for 94 selected lakes } \\
\text { on four continents (including Africa) derived from satellite } \\
\text { radar altimetry. Here, water-level is defined as the height } \\
\text { (in meters above the geoid) of the reflecting surface of } \\
\text { continental water bodies. Computed as a time series, water- } \\
\text { level is obtained from space radar altimeter observations } \\
\text { that measure the time taken by the radar pulses to reach the } \\
\text { ground targets directly below the spacecraft and back } \\
\text { (Calmant et al., 2013; Copernicus Climate Change } \\
\text { Services, 2020; Crétaux et al., 2011). The Water-level data } \\
\text { is available (as one value per lake per timestep) from 1992 } \\
\text { to present, downloaded from http://bit.ly/3bW19VV }\end{array}$ \\
& $\begin{array}{l}\text { We used the fifth version of a gridded NDVI derived from } \\
\text { the United States' National Oceanic and Atmospheric } \\
\text { Administration (NOAA)'s Climate Data Record (CDR) of } \\
\text { Advanced Very High-Resolution Radiometer (AVHRR) } \\
\text { Surface Reflectance. The dataset is available from 1981 to } \\
\text { near present, at 0.05 }{ }^{\circ} \text { by 0.05 }\end{array}$ \\
& $\begin{array}{l}\text { Normalized } \\
\text { Difference } \\
\text { Vegetation } \\
\text { Index (NDVI) }\end{array}$ &
\end{tabular}

Due to the differences in resolution and grids between precipitation observational and model data, processing and statistical computations were done in native grids and resolutions (as in Diaconescu et al., 2015). The final files were then bilinearly interpolated (as in Zhou et al., 2017) onto the CHIRPS regular grid to facilitate multi-model averaging and comparison between various model simulations and observations.

\subsection{Methods}

First, an analysis of Lake Victoria's water-level patterns was done using standardized annual water-level anomalies for the period 1993 - 2020, corresponding to the availability of water-level data from the Copernicus Global Land Service. By definition, standardized anomalies are computed by dividing deviations from the mean by standard deviation. They remove influences of location and spread from the data and make it easier to identify normal and above/below normal values in a dataset. Values between -1 and 1 are considered to fall between the normal range while values between 1 and 2 (-1 and -2) fall within the above (below) normal range. Values above (below) 2 (-2) are considered extreme (e.g., Dabernig et al., 2017; Grumm \& Hart, 2001). Standardized anomalies have been widely used in similar analyses (Awange et al., 2013; Dabernig et al., 2017; Scheuerer \& Büermann, 2014).

Secondly, the climatology of spatio-temporal precipitation patterns in the LVB were computed using a set of five annual extreme climate indices (Table 3) and mean annual (ANN) and seasonal (MAM, JJA, and OND) precipitation statistics. The indices, part of the Expert Team on Climate Change Detection and Indices (ETCCDI; https://www.wcrp-climate.org/etccdi) and are defined in detail in Zhang et al. (2011), adequately represent precipitation characteristics in study domain. 
Table 3. A description of extreme precipitation indices used in the study, obtained from Zhang et al. (2011)

\begin{tabular}{|c|c|c|c|}
\hline Descriptor & Acronym & Description & Unit \\
\hline $\begin{array}{l}\text { Simple precipitation } \\
\text { intensity index }\end{array}$ & SDII & $\begin{array}{l}\text { Mean precipitation amount on a wet day. Let } \\
\mathrm{RR}_{i j} \text { be the daily precipitation amount on wet } \\
\text { day } \mathrm{w}(\mathrm{RR} \geq 1 \mathrm{~mm}) \text { in period } j . \text { If } W \\
\text { represents the number of wet days in } j \text { then the } \\
\text { simple precipitation intensity index } \mathrm{SDII}_{\mathrm{j}}= \\
\text { sum }\left(\mathrm{RR}_{w j}\right) / \mathrm{W}\end{array}$ & $\mathrm{mm} /$ day \\
\hline Consecutive wet days & CWD & $\begin{array}{l}\text { Maximum length of wet spell, maximum } \\
\text { number of consecutive days with } \mathrm{RR} \geq 1 \mathrm{~mm} \text { : } \\
\text { Let } \mathrm{RR}_{i j} \text { be the daily precipitation amount on } \\
\text { day } i \text { in period } j \text {. Count the largest number of } \\
\text { consecutive days where: } \\
\mathrm{RR}_{\mathrm{ij}} \geq 1 \mathrm{~mm}\end{array}$ & Days \\
\hline $\begin{array}{l}\text { Number of wet days } \\
\text { with moderate } \\
\text { intensity precipitation }\end{array}$ & $\mathrm{R} 10 \mathrm{~mm}$ & $\begin{array}{l}\text { Defined as the number of days with } \\
\text { precipitation } \geq 10 \mathrm{~mm} / \text { day and representing } \\
\text { moderate intensity precipitation days }\end{array}$ & Days \\
\hline $\begin{array}{l}\text { Number of wet days } \\
\text { with heavy intensity } \\
\text { precipitation }\end{array}$ & $\mathrm{R} 30 \mathrm{~mm}$ & $\begin{array}{l}\text { Defined as the number of days with } \\
\text { precipitation } \geq 30 \mathrm{~mm} / \text { day and representing } \\
\text { heavy intensity precipitation days }\end{array}$ & Days \\
\hline $\begin{array}{l}\text { Max 5-day } \\
\text { precipitation amount }\end{array}$ & Rx5day & $\begin{array}{l}\text { Monthly maximum consecutive 5-day } \\
\text { precipitation }\end{array}$ & $\mathrm{mm}$ \\
\hline
\end{tabular}

Thirdly, an estimation of return periods for extreme precipitation events was done using a peakover-threshold method (as in van der Wiel et al., 2017; van Oldenborgh et al., 2017), with the extreme event values of interest fitted into a generalized extreme value (GEV) distribution given by

$$
F(x)=\exp \left[-\left(1+\xi \frac{x-\mu}{\sigma}\right)^{1 / \xi}\right] ; \quad \text { Equation } 1
$$

where $\mu=\mu_{0} \exp \left(\frac{\alpha T^{\prime}}{\mu_{0}}\right)$ and $\sigma=\sigma_{0} \exp \left(\frac{\alpha T^{\prime}}{\mu_{0}}\right)$ represent the location and scale parameters, respectively. The shape parameter of the curve is represented by $\xi$ and the ration $\sigma / \mu$ reduces to the constant $\sigma_{0} / \mu_{0}$. T represents a 4-year running mean of the global mean temperature (also referred to as smoothed GMST).

As detailed in van der Wiel et al. (2017), the maximum likelihood method is used to estimate the fit by varying $\sigma, \mu_{0}, \sigma_{0}$, and $\xi$. Here, a 0.2 width Gaussian is added to the likelihood function so that values greater than 0.4 are regarded as unphysical. Hence, fits are restrained to the 1000member nonparametric bootstrap used to estimate uncertainty (as in Efron \& Tibshirani, 1994). The presence of a trend is shown by the difference between the distributions with the range of 
uncertainty estimated with a 1000-member nonparametric bootstrap. The peak-over-threshold method has been used in various extreme event detection and attribution studies in East Africa (e.g., Uhe et al., 2018) and across the world (e.g., van der Wiel et al., 2017; van Oldenborgh et al., 2017). The analysis of return periods for extreme climate events is important for climate-induced risk management and mitigation (Vanem, 2015).

Further, the attribution of extreme precipitation events over the study domain was done using DAMIP model simulations. Here, differences in mean annual cycle statistics (ANN, MAM, JJA, and OND) between model simulations and reference data were computed to show the performance of CMIP6 GCMs in representing precipitation patterns over the study domain, over the period 1981-2014. The student $t$ test was used to compute significant differences in means of model simulations and observations (biases), at 99\% confidence interval. Additionally, the mean absolute errors (MAE; Equation 1) were used (calculated using detrended data) to rank the performance of the GCM simulations (relative to observations) in representing precipitation characteristics for our study domain. MAEs give the best measures of mean error magnitudes compared to other measures of dispersion (Chai \& Draxler, 2014; Willmott \& Matsuura, 2005).

$$
M A E=\frac{1}{n} \sum_{i=1}^{n}\left|y_{i}-x_{i}\right| \quad \text { Equation } 2
$$

where $n$ represents the number of observations while $x_{i}$ and $y_{i}$ represent observational and simulated values, respectively. The smaller the MAE, the better the simulation.

To assess the potential contribution of human-induced climate change on the observed precipitation patterns over the LVB, the fraction of attributable risk (FAR; Stott et al., 2004; Zhang et al., 2017). Here, FAR is defined as $1-\left(\mathrm{P}_{0} / \mathrm{P}_{1}\right)$, where $P_{0}$ is the probability of exceeding a given quantile under natural forcing while $P_{1}$ is the probability of exceeding the quantile under greenhouse gas (GHG) forcing. Using DAMIP data spanning 1850 to 2020 , the $90^{\text {th }}$ percentile values under natural forcing $\left(P_{0}\right)$ were used to identify corresponding percentile ranks in the data under GHG forcing $\left(P_{1}\right)$. Lastly, an analysis of land-use patterns over the study domain was done using standardized annual NDVI anomalies for the period 1981 to 2020.

\section{Results and discussion}

\subsection{Analysis of Lake Victoria's water-level patterns}

A plot of standardized anomalies for Lake Victoria's average annual water-levels (Figure 2) showed a decadal cycle. Here, positive values were recorded between 1993 and 2003 followed by negative values until 2013 after which positive values were recorded through 2020. Most of the fluctuations remained within the normal range (-1 and 1) except in 1998, 2019, and 2020 when above normal values $(>1)$ were recorded. Additionally, below normal values $(<-1)$ were recorded in 2006. 


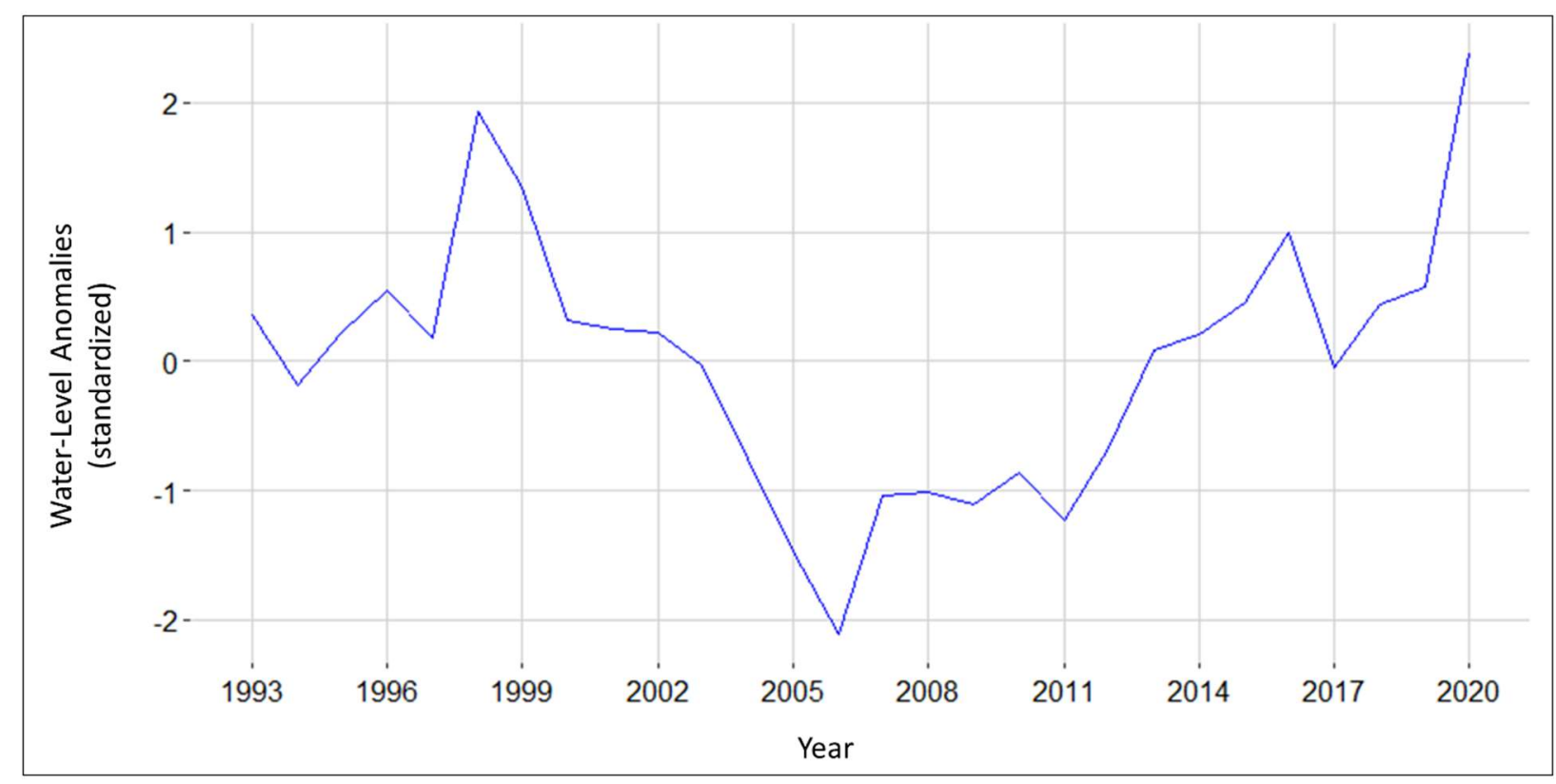

Figure 2. Standardized mean annual water-level anomalies (no units) for Lake Victoria for the period $1993-2020$

The high-water-levels of 1997/1998 have been attributed to extreme precipitation recorded in the region (Ngecu \& Mathu, 1999), triggered by a strong El Niño event of 1997/1998 (Bayer et al., 2014; Elliott et al., 2001). The 2006 low water-level corresponds to a severe drought observed in the region at the time (Hastenrath et al., 2007; Nicholson, 2014; Wakabi, 2006), possibly caused by a strong negative Indian Ocean Dipole in 2006 (Hastenrath et al., 2007). However, some studies (e.g., Sutcliffe \& Petersen, 2007) suggest that despite the 2005/2006 drought, lake water overabstraction related to the expansion of the Nalubaale dam in Uganda may have aggravated the low water-levels recorded in 2005/2006. The following section analyzes precipitation patterns over the study domain to explain the observed 2019/2020 high water-levels in Lake Victoria.

\subsection{Analysis of precipitation patterns over LVB}

A plot of precipitation climatology over the study domain (Figure 3) showed a relatively wetter precipitation regime over Lake Victoria than the rest of the domain. Consistent with literature (e.g., Yang et al., 2015), three distinct precipitation seasons were shown with MAM and OND being the main rainy seasons and JJA the relatively dry season. Here, more mean precipitation values were recorded for the MAM season than for OND, with average precipitation exceeding $8 \mathrm{~mm} /$ day over the western part of the lake during MAM. Over the lake-adjacent areas, higher precipitation values were recorded over western Kenya (eastern part of the study domain) than areas over Uganda and Tanzania (north-western and southern parts of the study domain, respectively). The mean daily precipitation for OND ranged from 2 to $8 \mathrm{~mm}$ /day compared to 2 to 6 (0 to 4$) \mathrm{mm}$ /day for ANN (JJA). The JJA season recorded drier/wetter conditions over the southern/northern part of the study domain. Considering the annual cycles (Figure 3, right panel), the MAM season seemed to begin early resulting in a February-May season relative to the 1981-2020 mean precipitation values. With some precipitation values being recorded for the JJA season, the study domain experienced an almost all-year round precipitation season as noted by earlier works (e.g., Herrmann \& Mohr, 2011; Nicholson, 2017). 


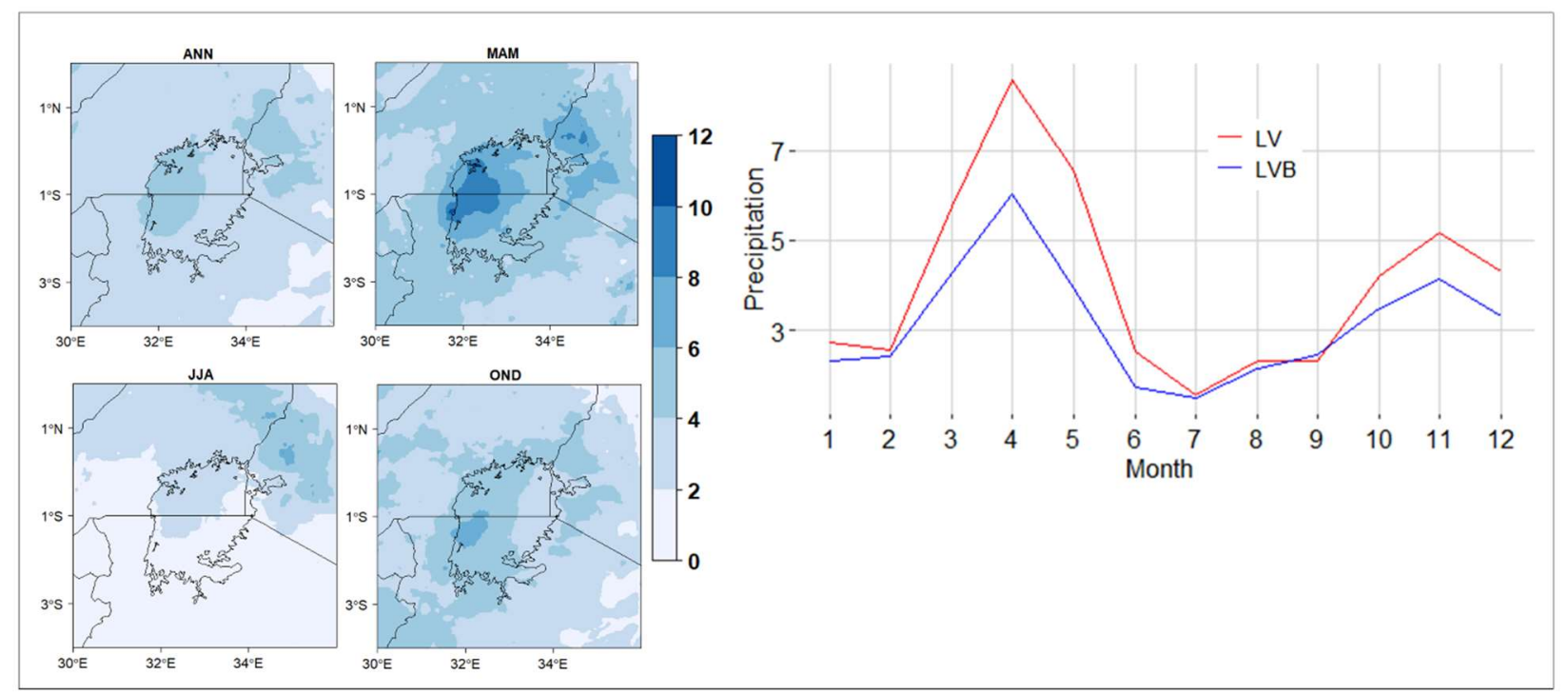

Figure 3. Mean daily annual (ANN) and seasonal (MAM, JJA, and OND) precipitation patterns over the study area, averaged for the period 1981-2020. The line plots represent annual precipitation cycles averaged over the study area (LVB; blue line) and a segment of Lake Victoria ( $L V$; red line). All units are in $\mathrm{mm} /$ day

An analysis of the interannual precipitation over the study domain (Figure 4) showed high variability albeit within the normal range (-1 to 1$)$. The highest standardized anomalies for OND were recorded in 1997 and 2019 while the only markable values for the JJA season were recorded in 2019. Except in 1984 and 1993 where extreme below normal values (-2.5 and -2.3, respectively) were recorded, no other discernible values were recorded for the MAM season. A similar pattern was observed for annual precipitation indices (Figure 4, bottom panel), where most of the values were within the normal range. Notably, the number of days with at least $10 \mathrm{~mm}$ of precipitation per day $(\mathrm{R} 10 \mathrm{~mm})$ showed a build-up from around 2015 reaching a peak (above normal values) in 2019. 


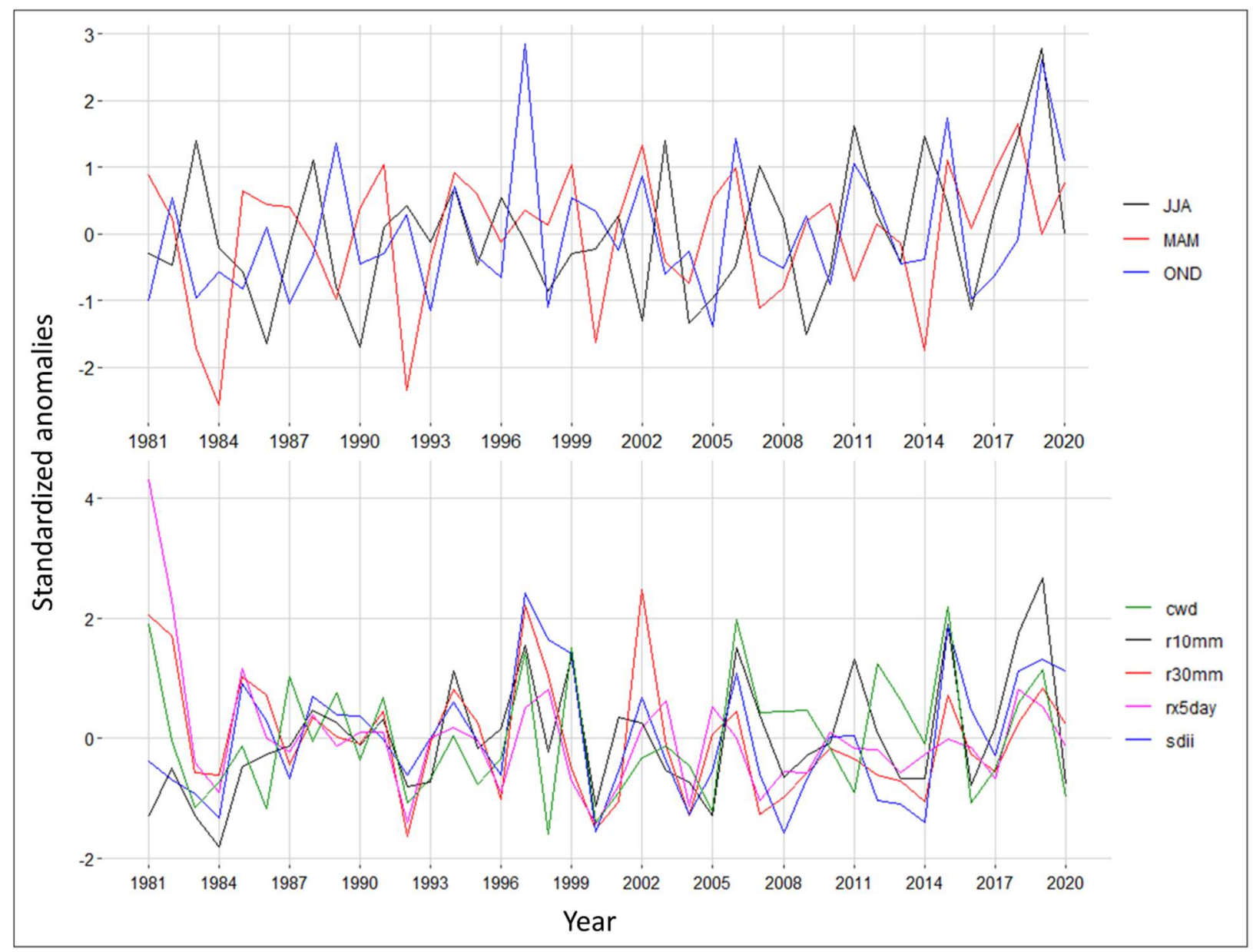

Figure 4. Standardized anomalies for seasonal precipitation statistics (top panel) and annual precipitation indices (bottom panel), averaged over a portion of Lake Victoria (32.2 to $33.8 \mathrm{oE}, 1.6$ to $0.4 \mathrm{oS})$, for the period 1981-2020. The standardized anomalies have no units

With reference to Figure 2 and Figure 4, the observed high water-levels of Lake Victoria in 2019 (Mafaranga, 2020) corresponded to unusually heavy and prolonged 2019 JJA and OND precipitation over the study domain. Hence, a further analysis of the two seasons (Figure 5) was done to pick long term variability patterns. Here, the three highest above-normal standardized anomalies for OND were recorded in 1961, 2019, and 1951, respectively. The only above-normal standardized anomaly value recorded for JJA was in 2019. Unlike in 1961 when the only extreme precipitation values recorded were for OND season, extreme precipitation values were recorded for both JJA and OND seasons in 2019. 


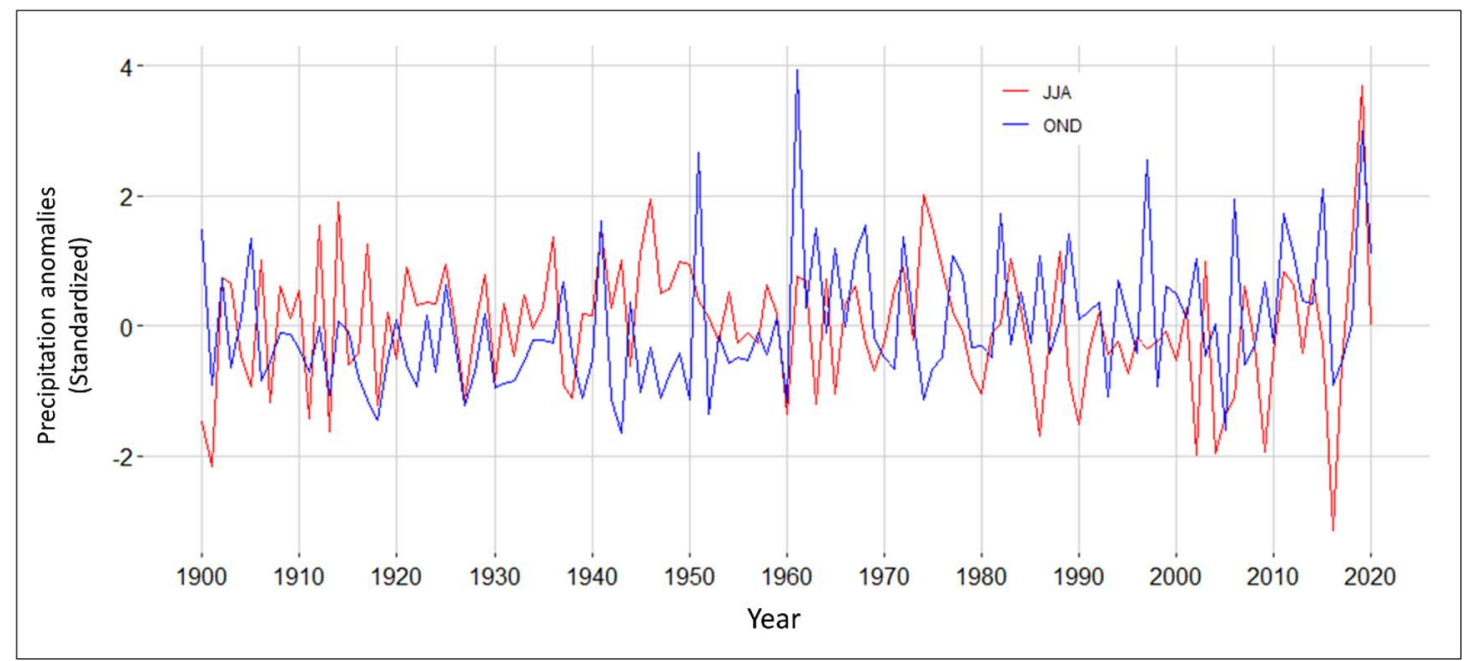

Figure 5. As in Figure 4 but only for JJA and OND, using CenTrendsChirps data for the period 1900-2020

A plot of generalized extreme value (GEV) distribution fits for the 2019 JJA and OND precipitation at a point at the western part of Lake Victoria (Figure 1, point B) showed return periods of about 260.3 and 7990.5 for JJA and OND respectively (Figure 6). When scaled down to the climate of 1950 (2000), return periods of 48.7 (126.3) and 737.0 (2765.4) were recorded for JJA and OND, respectively. This implies that the 2019 JJA event was 11 times less likely to happen in 1950 and 3 times less likely to happen in 2000. The 2019 OND precipitation event was 2 times less likely to happen in 2000 and 5 times less likely to happen in 1950.

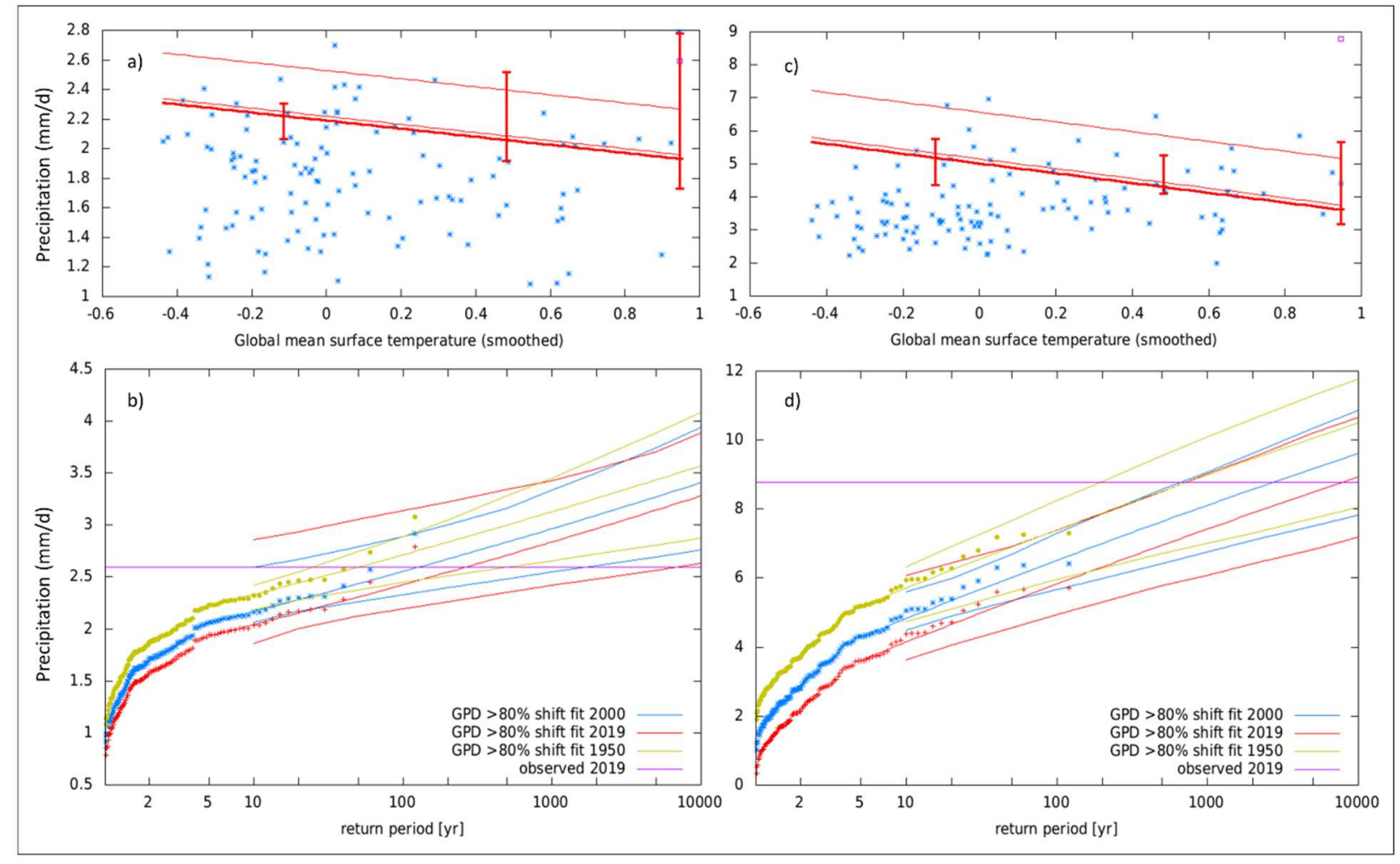

Figure 6. Mean JJA $(a, b)$ and OND (c, d) precipitation at 0.6 oS 31.9 oE fitted to a GEV that scales with smoothed global mean surface temperature. Values for 2019 are represented by the purple square while the bold red line represents the location 
parameter $(\mu)$, the faint red lines representing $\mu+\sigma$ and $\mu+2 \sigma$, and the two vertical red lines showing $\mu$ and its $95 \%$ confidence interval for the two climates in (b) and (d). The return periods for the 2019 JJA and OND precipitation are presented in (b) and (d), respectively. Values for events under investigation (shown in red + signs) were shifted to the climate of 1950 with the fitted trend (in yellow $\square$ signs) and the climate of 2000 (in blue * signs). In (b) and (d), the GPD and its 95\% confidence interval is represented by the red, yellow, and blue lines 2019, 1950, and 2000, respectively. Values for 2019 (excluded from the fit) are shown as horizontal purple lines. All units are in $\mathrm{mm} / \mathrm{day}$

Looking at a summary of return periods for the 2019 and 1961 JJA and OND precipitation events at select locations on Lake Victoria (Table 4), the rarest JJA events were recorded at the western (1-in-260 years), central (1-in-64 years), and northern (1-in-45 years) parts of the lake, respectively. The eastern and southern parts of the lake showed no discernible variations in the likelihood of occurrence of the JJA and OND precipitation events. Conversely, the likelihood of occurrence for the $2019 \mathrm{JJA}$ event over the central (northern) parts of the lake increased by factors of 2 and 6 (1.5 and 2.6) when downscaled to the climates of 2000 and 1950, respectively. No discernible changes were observed in the eastern and southern parts of the lake for the $2019 \mathrm{JJA}$ event.

Table 4. Return periods for 1961 and 2019 JJA and OND precipitation events at select locations on Lake Victoria, presented on Figure 1 as A, B, C, D and E for Centre, West, East, South, and North, respectively. Values within the 95\% confidence interval are shown in brackets

\begin{tabular}{|c|c|c|c|c|c|}
\hline Location & \multicolumn{2}{|c|}{$\begin{array}{c}\text { Year and season } \\
\text { of event }\end{array}$} & $\begin{array}{l}\text { Return period at } \\
\text { event year }\end{array}$ & $\begin{array}{c}\text { Return period if } \\
\text { downscaled to } 1950\end{array}$ & $\begin{array}{l}\text { Return period if } \\
\text { upscaled to } 2000\end{array}$ \\
\hline \multirow{4}{*}{$\begin{array}{c}\text { Centre } \\
\left(1.07^{\circ} \mathrm{S}\right. \\
\left.32.8^{\circ} \mathrm{E}\right)\end{array}$} & \multirow[t]{2}{*}{1961} & JJA & $5.5(3.6-9.6)$ & $6.8(4.5-12.3)$ & $4.0(2.0-10.4)$ \\
\hline & & OND & $\begin{array}{c}695.0(197.1- \\
20708.0)\end{array}$ & $\begin{array}{c}555.6(147.2- \\
30267.0)\end{array}$ & $\begin{array}{c}1475.5(334.3- \\
29996.0)\end{array}$ \\
\hline & \multirow[t]{2}{*}{2019} & JJA & $\begin{array}{l}63.9(4.7- \\
4792.1)\end{array}$ & $\begin{array}{c}382.3(120.8- \\
8385.9)\end{array}$ & $\begin{array}{c}140.5(26.3- \\
3959.8)\end{array}$ \\
\hline & & OND & $17.7(3.0-108.3)$ & $4.7(3.2-11.3)$ & $9.7(4.3-24.3)$ \\
\hline \multirow{4}{*}{$\begin{array}{c}\text { West } \\
\left(0.6^{\circ} \mathrm{S},\right. \\
\left.31.9^{\circ} \mathrm{E}\right)\end{array}$} & \multirow[t]{2}{*}{1961} & JJA & $22.6(13-65.0)$ & $25.8(14.7-86.1)$ & $14.7(3.5-111.6)$ \\
\hline & & OND & $\begin{array}{c}164.4(67.3- \\
1778.9)\end{array}$ & $\begin{array}{c}225.2(91.1- \\
4690.0)\end{array}$ & $57.3(5.4-280.8)$ \\
\hline & \multirow[t]{2}{*}{2019} & JJA & $\begin{array}{c}260.3(3.2- \\
6791)\end{array}$ & $48.7(24.3-486.0)$ & $\begin{array}{c}126.3(10- \\
1700.6)\end{array}$ \\
\hline & & OND & $\begin{array}{c}7990.5(739.1- \\
0.37 \mathrm{E}+06)\end{array}$ & $\begin{array}{c}737.0(195.2- \\
65800)\end{array}$ & $\begin{array}{c}2765.4(677.3- \\
0.1 \mathrm{E}+06)\end{array}$ \\
\hline \multirow{4}{*}{$\begin{array}{c}\text { East } \\
\left(0.3^{\circ} \mathrm{S},\right. \\
\left.34.1^{\circ} \mathrm{E}\right)\end{array}$} & \multirow[t]{2}{*}{1961} & JJA & $1.6(1.4-1.9)$ & $1.6(1.3-1.9)$ & $1.6(1.3-2.0)$ \\
\hline & & OND & $\begin{array}{c}3364.8(560.7- \\
0.4 \mathrm{E}+06)\end{array}$ & $\begin{array}{c}7480.1(1133.6- \\
0.31 \mathrm{E}+07)\end{array}$ & $\begin{array}{c}255.0(12.5- \\
2438.3)\end{array}$ \\
\hline & \multirow[t]{2}{*}{2019} & JJA & $3.3(1.4-15.0)$ & $3.1(2.3-4.3)$ & $3.1(1.8-5.8)$ \\
\hline & & OND & $2.9(1.2-19.0)$ & $\begin{array}{c}483.0(122.6- \\
20682.0)\end{array}$ & $21.1(2.8-168.3)$ \\
\hline \multirow{3}{*}{$\begin{array}{l}\text { South } \\
\left(2.4^{\circ} \mathrm{S} \text {, }\right. \\
\left.32.8^{\circ} \mathrm{E}\right)\end{array}$} & \multirow[t]{2}{*}{1961} & JJA & $3.2(2.4-6.2)$ & $3.1(2.4-4.2)$ & $3.6(2.4-6.2)$ \\
\hline & & OND & $\begin{array}{c}1792.3(535.6- \\
93674.1)\end{array}$ & $\begin{array}{c}3787.4(1006.1- \\
0.3 \mathrm{E}+06)\end{array}$ & $\begin{array}{c}175.3(12.9- \\
3810.6)\end{array}$ \\
\hline & 2019 & JJA & $13.7(3.9-230.7)$ & $5.6(3.6-11.0)$ & $9.3(4.9-34.1)$ \\
\hline
\end{tabular}




\begin{tabular}{|c|c|c|c|c|c|}
\hline & & OND & $\begin{array}{c}12.2(91.3- \\
149.3)\end{array}$ & $\begin{array}{c}123.8(45.6- \\
2742.2)\end{array}$ & $33.5(4.0-179.1)$ \\
\hline North & \multirow{2}{*}{1961} & JJA & $10.4(4.8-20.6)$ & $13.5(8.2-31.2)$ & $4.7(2.3-21.8)$ \\
\cline { 3 - 6 }$\left(0.2^{\circ} \mathrm{N}\right.$, & & OND & $1225.5(191.3-$ & $3094.0(596.0-$ & $70.2(3.6-$ \\
$\left.33.1^{\circ} \mathrm{E}\right)$ & & & $95211.1)$ & $0.63 \mathrm{E}+06)$ & $1431.7)$ \\
\cline { 3 - 6 } & \multirow{2}{*}{2019} & JJA & $44.6(2.4-$ & $116.42(43.4-$ & $67.8(5.5-$ \\
& & & $3331.1)$ & $1841.3)$ & $1048.2)$ \\
\cline { 3 - 6 } & & OND & $16.5(1.5-531.6)$ & $878.4(260.5-$ & $94.0(6.5-$ \\
& & & & $72969.0)$ & $2280.4)$ \\
\hline
\end{tabular}

The 2019 OND precipitation showed a similar trend with that of the 2019 JJA precipitation event. When averaged over Lake Victoria, the OND precipitation event of 2019 was a 1-in-52-year event, compared to 1961 's 1-in-693 years. Additionally, a high spatial precipitation variability was shown on the lake with various parts recording different return periods, especially for the 2019 JJA and OND precipitation events.

\subsubsection{Extreme Event Attribution using DAMIP GCM simulations}

A plot of mean annual (ANN) and seasonal (MAM, JJA, and OND) precipitation differences between model simulations (an ensemble mean) and observations (Figure 7) showed significant biases between models and observations. Here, the model simulations under-estimated MAM and JJA precipitation over most of the study area and over-estimated values for OND. However, most differences range between -50 and $50 \mathrm{~mm} / \mathrm{month}$. 


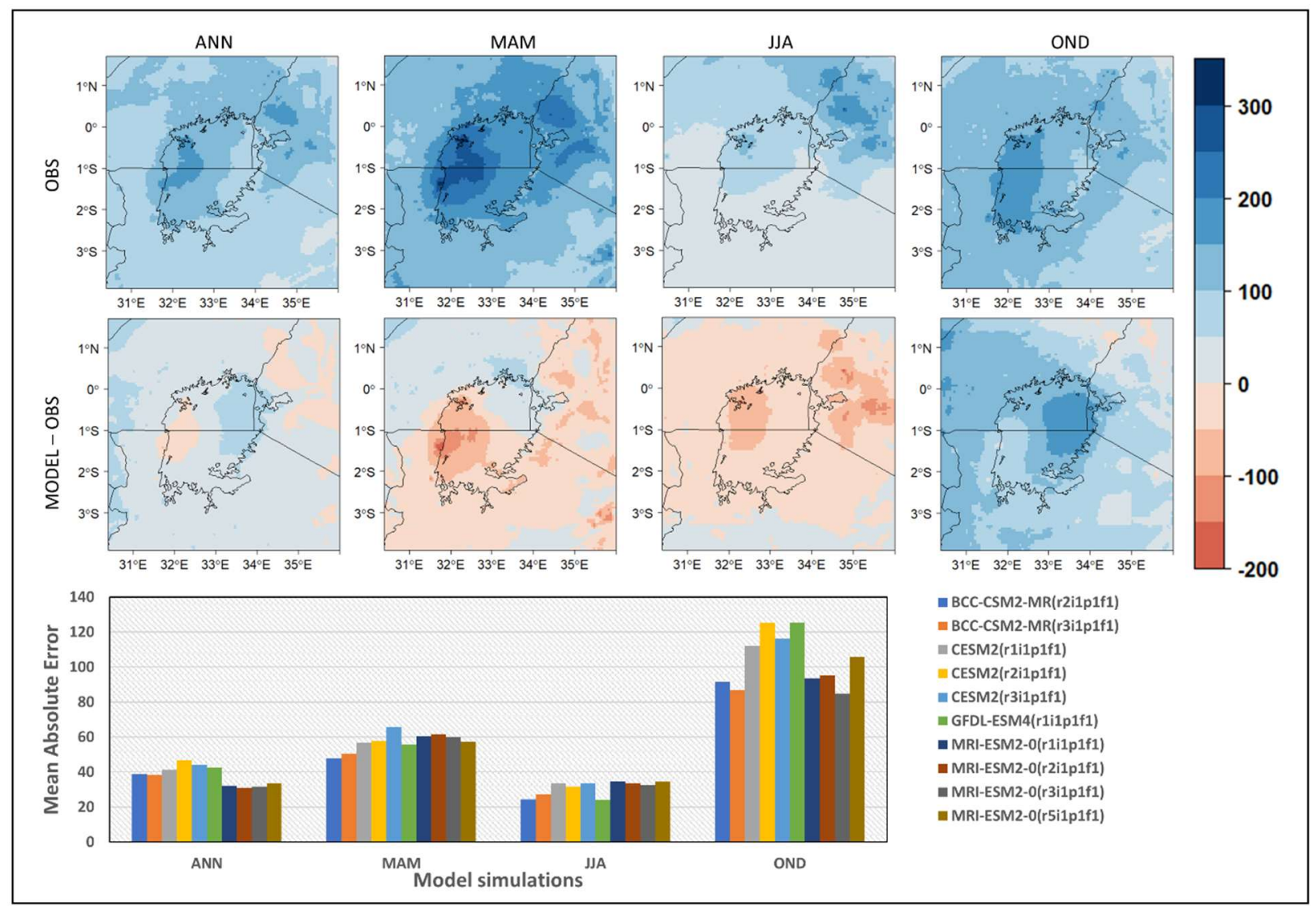

Figure 7. Precipitation climatology (OBS, top panel) and differences in mean precipitation between DAMIP model simulations (ensemble mean) and observations (MODEL - OBS, middle panel), averaged for annual (ANN) and seasonal (MAM, JJA, and OND) precipitation, for the period 1981-2014. The mean absolute errors (relative to observations) for individual DAMIP model simulations are presented as histograms (bottom panel). Nearly all MODEL - OBS values are significant at 99\% confidence interval and all units are in $\mathrm{mm} / \mathrm{month}$

Looking at the mean absolute errors (Figure 7, bottom panel), the greatest/least model simulation biases (relative to observations) were recorded in the OND/JJA season. The performance of the model simulations was category-specific, with simulations from the MRI-ESM2-0 showing superior (inferior) performance for ANN (MAM and JJA) category. Simulations from the BCCCSM2-MR and GFDL-ESM4 models gave the best reproduction for MAM and JJA while the OND season was best reproduced by simulations from the MRI-ESM2-0 and BCC-CSM2-MR models. The relatively better performance of the MRI-ESM2-0 and BCC-CSM2-MR models have also been noted elsewhere (e.g., Yazdandoost et al., 2021). The observed intermodal differences in reproducing precipitation patterns over the study domain was possibly due to the complexity of the LVB enhanced by, in part, topography and localized climate systems (e.g., Smith \& Semazzi, 2014; Thiery et al., 2015, 2016; Williams et al., 2015). CMIP6 model simulations have also been found to underestimate precipitation in areas with heavy precipitation trends (e.g., Yazdandoost et al., 2021). Nonetheless, the observed MAEs were marginal with the highest bias being 125.4 $\mathrm{mm} / \mathrm{month}$.

Negative fraction of attributable risk (FAR) values for the JJA season (Figure 8) were recorded over most of the study domain. Most of the model simulations used agree on the negative FAR signal over most parts of the domain with a few lake-adjacent areas recording positive values. The 
negative FAR values imply that the JJA precipitation patterns over the lake are mainly forced by natural variability rather than human-induced climate change.

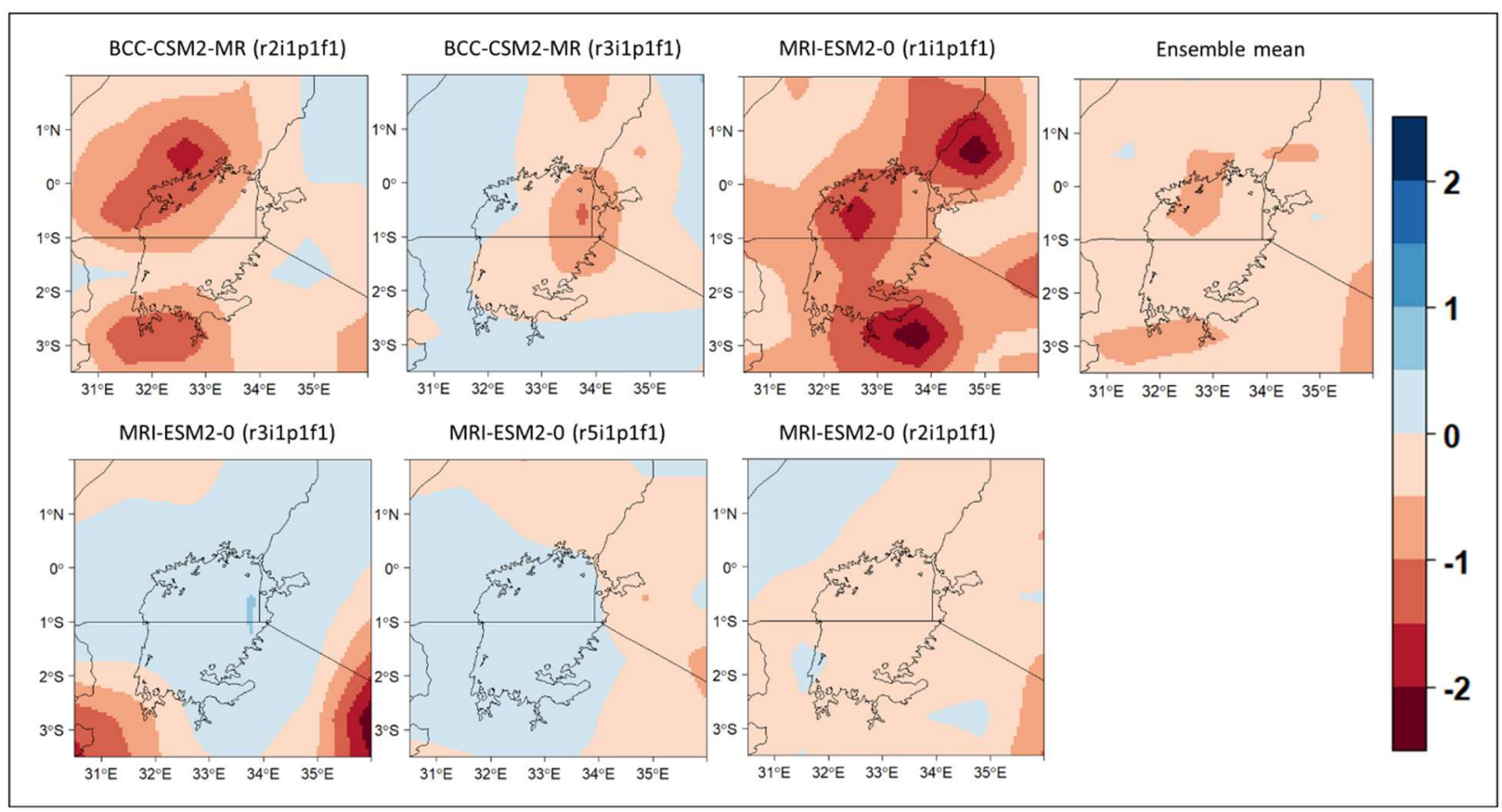

Figure 8. FAR values for mean JJA precipitation calculated using the historical (1850-2019) DAMIP data under natural forcing and $G H G$ forcing

FAR values for the OND season (Figure 9) showed a general model simulation agreement. Here, positive FAR values of about 0.5 were recorded over non-lake areas of the study domain, implying a strong influence of human-induced climate change on the OND precipitation patterns. Over the lake, most model simulations showed negative FAR values implying that natural variability had a greater influence on the OND precipitation patterns over Lake Victoria than human-induced climate change. 


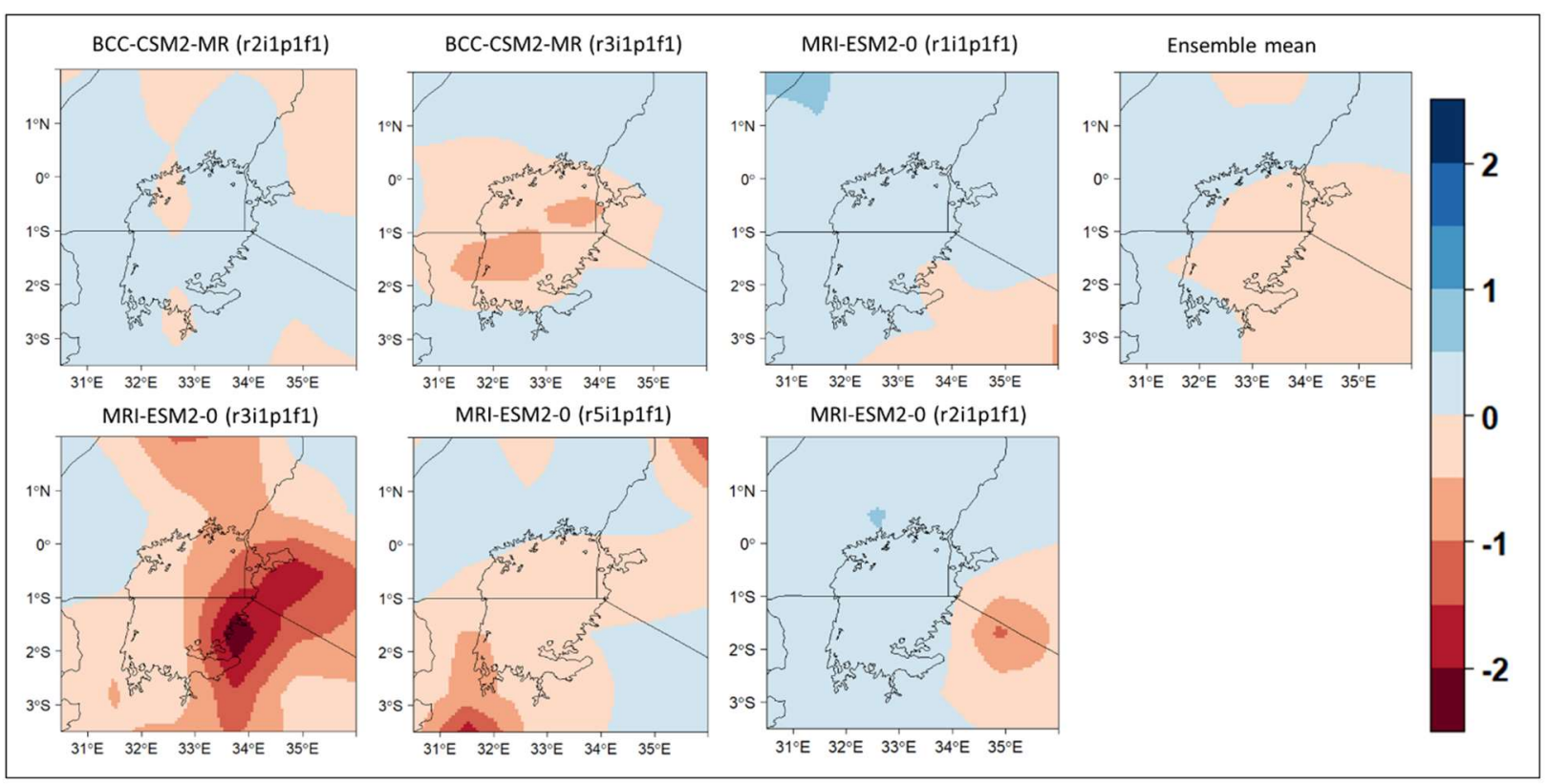

Figure 9. As in Figure 8 but for OND

This study enhances the understanding of spatio-temporal precipitation change and variability in the Lake Victoria region. While the lake's water budget is primarily drawn from direct precipitation, human-induced changes in precipitation patterns in the lake-adjacent areas may vary the contribution of lake inflows from the catchment's rivers. Given the sensitivity of Lake Victoria to climatic variability (Anyah et al., 2006; J. L. Awange et al., 2013; Olaka et al., 2019; Thiery et al., 2015), findings from the current study will be useful in informing the strategies on the use of the lake's water resources.

\subsection{Analysis of Land use Patterns over LVB}

A plot of NDVI anomalies averaged over the study domain (Figure 10) showed a general increase in mean vegetative cover with a peak in 1999 before a gradual descent through 2020 . The apparent drop in the study domain's vegetative cover from the early 2000s may have been caused by intensification of agricultural activities at the expense of forest cover. East Africa's farmed land had significantly increased (by about 34\%) since the early 2000s, resulting primarily from the conversion of open and wooded grasslands and open forests to cropped areas (Bullock et al., 2021). Other possible drivers of the observed land use changes include the clearance of forest land for non-agricultural uses, and unsustainable extraction of forest products (Odada et al., 2004; Song et al., 2018; Waiswa et al., 2015). 


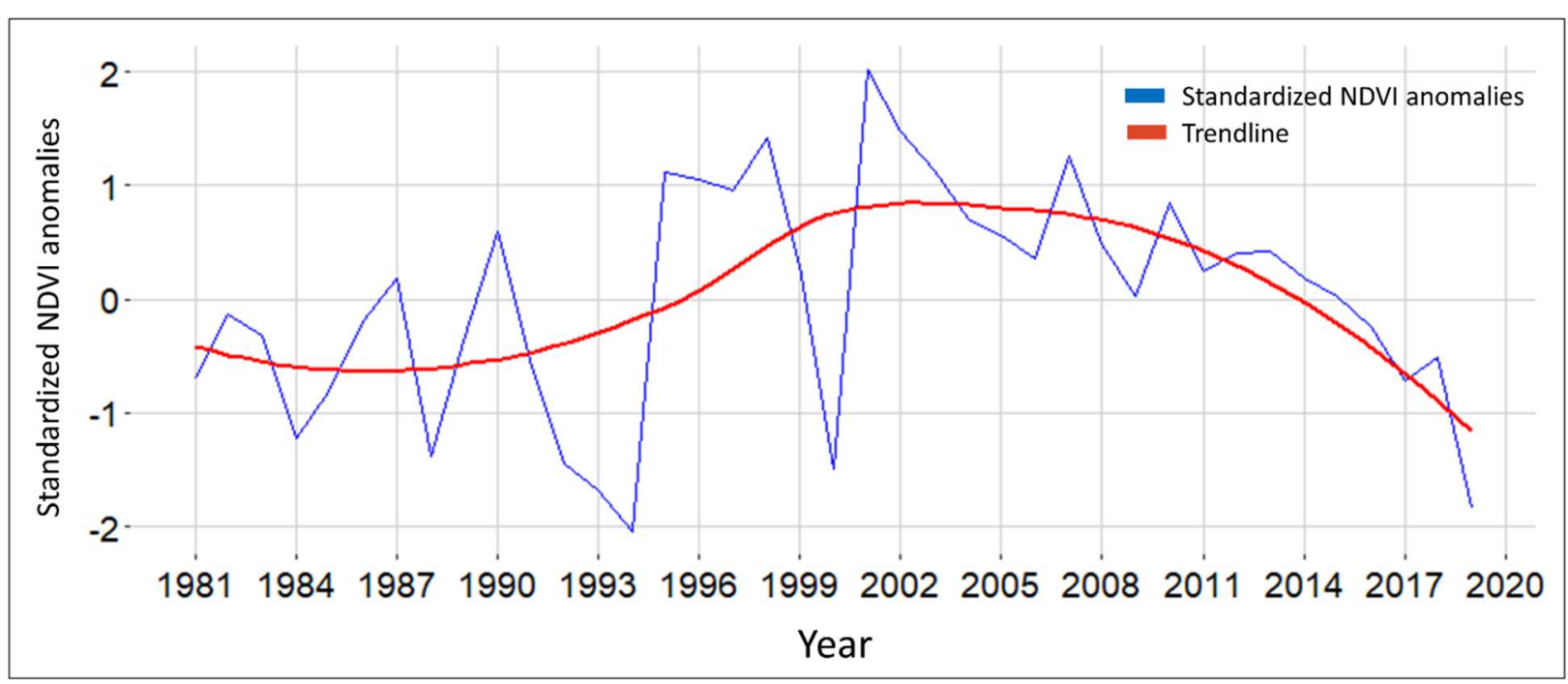

Figure 10. Mean annual NDVI anomalies averaged over the LVB for the period 1981 - 2019. NDVI values are unitless

A reducing mean land-cover may have minimized the LVB's capacity to hold flood waters hence increasing the size of the runoff coefficient (e.g., Bradshaw et al., 2007; Kundzewicz et al., 2014). Consequently, the catchment's river flow and flood water regulation ability may have reduced over time resulting in more water ending up in Lake Victoria per unit time. Given the significant role played by population and agricultural efficiency on the extent of an area's vegetative cover (Stehfest et al., 2019), there is need for enhanced sound land use regulation to enable the LVB increase its capacity to regulate river flow and flood waters and, ultimately, reduce the runoff coefficient.

\section{Conclusion and recommendations}

The 2019 high water-levels observed in Lake Victoria coincided with unusually heavy precipitation over the study domain at the same time. The domain's mean land-cover was also at its lowest during 2019. Comparing the 2019 precipitation values to those in 1961 when similar high water-levels were observed in Lake Victoria, 2019 had extreme values recorded in JJA and OND while the only extreme values recorded in 1961 were for the OND season. An analysis of return periods using mean precipitation values over Lake Victoria showed the 2019 OND event to be a 1-in-52-year event, which was 13 times more likely to occur than the 1961 OND event. Hence, the extended and unusually heavy June to December 2019 precipitation in the study domain bore the greatest responsibility for Lake Victoria's high water-levels of 2019/2020.

An analysis of FAR values showed natural variability to have a greater influence on the JJA and OND precipitation patterns over Lake Victoria than human-induced climate change. However, variability over the land area of the study domain was mainly driven by human-induced climate change rather than natural variability, a unique climate system over Lake Victoria compared to the rest of the study domain. Further, the difference in return periods at various parts of the lake imply a high spatial climate variability within the lake itself.

Further research is recommended to enhance the understanding of Lake Victoria's water budget in the phase of a changing climate and land-use change in the LVB. More work is required to quantify 
the exact contribution of direct precipitation, inflow from the rivers, discharge through the White Nile River and groundwater percolation, and evaporation. Additionally, the observed reduction in vegetative cover needs to be checked to restore the study domain's capacity to regulate river flow and flood waters. Ultimately, an enhanced understanding of Lake Victoria's water budget will be useful for strategies on the planning and use of the LVB's water resources. Enhanced monitoring of the lake's water-level fluctuations is required to mitigate the risk of aquatic ecosystem destruction and proactively respond to potential aquatic ecosystem service losses posed by extreme lake water-level fluctuations.

\section{Acknowledgment}

The authors appreciate the contribution of various organizations whose datasets made the current study possible. The authors also acknowledge and appreciate the availability of the KNMI Climate Explorer climate data analysis toolkit. The anonymous reviewers whose comments helped shape this article are also appreciated. Errors, if any, are those of the authors and not the institutions to which they are affiliated.

\section{References}

Anyah, R. O., Semazzi, F. H. M., \& Xie, L. (2006). Simulated Physical Mechanisms Associated with Climate Variability over Lake Victoria Basin in East Africa. Monthly Weather Review, 134(12), 3588-3609. https://doi.org/10.1175/MWR3266.1

Awange, J. L., Anyah, R., Agola, N., Forootan, E., \& Omondi, P. (2013). Potential impacts of climate and environmental change on the stored water of Lake Victoria Basin and economic implications. Water Resources Research, 49(12), 8160-8173. https://doi.org/10.1002/2013WR014350

Awange, Joseph L., Ogalo, L., Bae, K.-H., Were, P., Omondi, P., Omute, P., \& Omullo, M. (2008). Falling Lake Victoria water levels: Is climate a contributing factor? Climatic Change, 89(3-4), 281-297. https://doi.org/10.1007/s10584-008-9409-X

Awange, Joseph L., Sharifi, M. A., Ogonda, G., Wickert, J., Grafarend, E. W., \& Omulo, M. A. (2008). The Falling Lake Victoria Water Level: GRACE, TRIMM and CHAMP Satellite Analysis of the Lake Basin. Water Resources Management, 22(7), 775-796. https://doi.org/10.1007/s11269-007-9191-y

Bai, L., Shi, C., Li, L., Yang, Y., \& Wu, J. (2018). Accuracy of CHIRPS Satellite-Rainfall Products over Mainland China. Remote Sensing, 10(3), 362. https://doi.org/10.3390/rs10030362

Bayer, A. M., Danysh, H. E., Garvich, M., Gonzálvez, G., Checkley, W., Álvarez, M., \& Gilman, R. H. (2014). An unforgettable event: a qualitative study of the 1997-98 El Niño in northern Peru. Disasters, 38(2), 351-374. https://doi.org/10.1111/disa.12046

Bradshaw, C. J. A., SODHI, N. S., PEH, K. S.-H., \& BROOK, B. W. (2007). Global evidence that deforestation amplifies flood risk and severity in the developing world. Global Change Biology, 13(11), 2379-2395. https://doi.org/10.1111/j.1365-2486.2007.01446.x

Bullock, E. L., Healey, S. P., Yang, Z., Oduor, P., Gorelick, N., Omondi, S., Ouko, E., \& Cohen, W. B. (2021). Three Decades of Land Cover Change in East Africa. Land, 10(2), 150. https://doi.org/10.3390/land10020150

Calmant, S., da Silva, J. S., Moreira, D. M., Seyler, F., Shum, C. K., Crétaux, J. F., \& Gabalda, G. (2013). Detection of Envisat RA2/ICE-1 retracked radar altimetry bias over the Amazon 
basin rivers using GPS. Advances in Space Research, 51(8), 1551-1564. https://doi.org/10.1016/j.asr.2012.07.033

Chai, T., \& Draxler, R. R. (2014). Root mean square error (RMSE) or mean absolute error (MAE)? - Arguments against avoiding RMSE in the literature. Geoscientific Model Development, 7(3), 1247-1250. https://doi.org/10.5194/gmd-7-1247-2014

Copernicus Climate Change Services (2020). Lake water levels from 1992 to present derived from satellite observations. https://doi.org/https://doi.org/10.24381/cds.5714c668

Crétaux, J.-F., Jelinski, W., Calmant, S., Kouraev, A., Vuglinski, V., Bergé-Nguyen, M., Gennero, M.-C., Nino, F., Abarca Del Rio, R., Cazenave, A., \& Maisongrande, P. (2011). SOLS: A lake database to monitor in the Near Real Time water level and storage variations from remote sensing data. Advances in Space Research, 47(9), 1497-1507.

https://doi.org/10.1016/j.asr.2011.01.004

Dabernig, M., Mayr, G. J., Messner, J. W., \& Zeileis, A. (2017). Spatial ensemble postprocessing with standardized anomalies. Quarterly Journal of the Royal Meteorological Society, 143(703), 909-916. https://doi.org/10.1002/qj.2975

Danabasoglu, G., Lamarque, J. -F., Bacmeister, J., Bailey, D. A., DuVivier, A. K., Edwards, J., Emmons, L. K., Fasullo, J., Garcia, R., Gettelman, A., Hannay, C., Holland, M. M., Large, W. G., Lauritzen, P. H., Lawrence, D. M., Lenaerts, J. T. M., Lindsay, K., Lipscomb, W. H., Mills, M. J., ... Strand, W. G. (2020). The Community Earth System Model Version 2 (CESM2). Journal of Advances in Modeling Earth Systems, 12(2).

https://doi.org/10.1029/2019MS001916

Di Baldassarre, G., Elshamy, M., van Griensven, A., Soliman, E., Kigobe, M., Ndomba, P., Mutemi, J., Mutua, F., Moges, S., Xuan, Y., Solomatine, D., \& Uhlenbrook, S. (2011). Future hydrology and climate in the River Nile basin: a review. Hydrological Sciences Journal, 56(2), 199-211. https://doi.org/10.1080/02626667.2011.557378

Diaconescu, E. P., Gachon, P., \& Laprise, R. (2015). On the Remapping Procedure of Daily Precipitation Statistics and Indices Used in Regional Climate Model Evaluation. Journal of Hydrometeorology, 16(6), 2301-2310. https://doi.org/10.1175/JHM-D-15-0025.1

Dinku, T., Funk, C., Peterson, P., Maidment, R., Tadesse, T., Gadain, H., \& Ceccato, P. (2018). Validation of the CHIRPS satellite rainfall estimates over eastern Africa. Quarterly Journal of the Royal Meteorological Society, 144(S1), 292-312. https://doi.org/10.1002/qj.3244

Dunne, J. P., Horowitz, L. W., Adcroft, A. J., Ginoux, P., Held, I. M., John, J. G., Krasting, J. P., Malyshev, S., Naik, V., Paulot, F., Shevliakova, E., Stock, C. A., Zadeh, N., Balaji, V., Blanton, C., Dunne, K. A., Dupuis, C., Durachta, J., Dussin, R., ... Zhao, M. (2020). The GFDL Earth System Model Version 4.1 (GFDL-ESM 4.1): Overall Coupled Model Description and Simulation Characteristics. Journal of Advances in Modeling Earth Systems, 12(11). https://doi.org/10.1029/2019MS002015

Efron, B., \& Tibshirani, R. J. (1994). An Introduction to the Bootstrap (1st ed.). Chapman and Hall/CRC.

Elliott, J. R., Jewson, S. P., \& Sutton, R. T. (2001). The Impact of the 1997/98 E1 Niño Event on the Atlantic Ocean. Journal of Climate, 14(6), 1069-1077. https://doi.org/10.1175/15200442(2001)014<1069:TIOTEN>2.0.CO;2

Eyring, V., Bony, S., Meehl, G. A., Senior, C. A., Stevens, B., Stouffer, R. J., \& Taylor, K. E. (2016). Overview of the Coupled Model Intercomparison Project Phase 6 (CMIP6) experimental design and organization. Geoscientific Model Development, 9(5), 1937-1958. https://doi.org/10.5194/gmd-9-1937-2016 
Faramarzi, M., Abbaspour, K. C., Ashraf Vaghefi, S., Farzaneh, M. R., Zehnder, A. J. B., Srinivasan, R., \& Yang, H. (2013). Modeling impacts of climate change on freshwater availability in Africa. Journal of Hydrology, 480, 85-101. https://doi.org/10.1016/j.jhydrol.2012.12.016

Funk, C., Nicholson, S. E., Landsfeld, M., Klotter, D., Peterson, P., \& Harrison, L. (2015). The Centennial Trends Greater Horn of Africa precipitation dataset. Scientific Data, 2(1), 150050. https://doi.org/10.1038/sdata.2015.50

Funk, C., Peterson, P., Landsfeld, M., Pedreros, D., Verdin, J., Shukla, S., Husak, G., Rowland, J., Harrison, L., Hoell, A., \& Michaelsen, J. (2015). The climate hazards infrared precipitation with stations - a new environmental record for monitoring extremes. Scientific Data, 2(1), 150066. https://doi.org/10.1038/sdata.2015.66

Gebrechorkos, S. H. (2019). Changes in temperature and precipitation extremes in Ethiopia ,. February 2018, 18-30. https://doi.org/10.1002/joc.5777

Geleta, C. D., \& Deressa, T. A. (2021). Evaluation of Climate Hazards Group InfraRed Precipitation Station (CHIRPS) $<\mathrm{scp}>$ satellite-based $</ \mathrm{scp}>$ rainfall estimates over Finchaa and Neshe Watersheds, Ethiopia. Engineering Reports, 3(6). https://doi.org/10.1002/eng2.12338

Gillett, N. P., Shiogama, H., Funke, B., Hegerl, G., Knutti, R., Matthes, K., Santer, B. D., Stone, D., \& Tebaldi, C. (2016). The Detection and Attribution Model Intercomparison Project (DAMIP v1.0) contribution to CMIP6. Geoscientific Model Development, 9(10), 36853697. https://doi.org/10.5194/gmd-9-3685-2016

Grumm, R. H., \& Hart, R. (2001). Standardized Anomalies Applied to Significant Cold Season Weather Events: Preliminary Findings. Weather and Forecasting, 16(6), 736-754. https://doi.org/10.1175/1520-0434(2001)016<0736:SAATSC $>2.0 . C O ; 2$

Hastenrath, S., Polzin, D., \& Mutai, C. (2007). Diagnosing the 2005 Drought in Equatorial East Africa. Journal of Climate, 20(18), 4628-4637. https://doi.org/10.1175/JCLI4238.1

Herrmann, S. M., \& Mohr, K. I. (2011). A Continental-Scale Classification of Rainfall Seasonality Regimes in Africa Based on Gridded Precipitation and Land Surface Temperature Products. Journal of Applied Meteorology and Climatology, 50(12), 2504 2513. https://doi.org/10.1175/JAMC-D-11-024.1

Kawai, H., Yukimoto, S., Koshiro, T., Oshima, N., Tanaka, T., Yoshimura, H., \& Nagasawa, R. (2019). Significant improvement of cloud representation in the global climate model MRIESM2. Geoscientific Model Development, 12(7), 2875-2897. https://doi.org/10.5194/gmd$12-2875-2019$

Kite, G. W. (1981). Recent changes in level of Lake Victoria / Récents changements enregistrés dans le niveau du Lac Victoria. Hydrological Sciences Bulletin, 26(3), 233-243. https://doi.org/10.1080/02626668109490883

Kiwanuka-Tondo, J., Semazzi, F., \& Pettiway, K. (2019). Climate risk communication of navigation safety and climate conditions over Lake Victoria basin: Exploring perceptions and knowledge of indigenous communities. Cogent Social Sciences, 5(1). https://doi.org/10.1080/23311886.2019.1588485

Kundzewicz, Z. W., Kanae, S., Seneviratne, S. I., Handmer, J., Nicholls, N., Peduzzi, P., Mechler, R., Bouwer, L. M., Arnell, N., Mach, K., Muir-Wood, R., Brakenridge, G. R., Kron, W., Benito, G., Honda, Y., Takahashi, K., \& Sherstyukov, B. (2014). Flood risk and climate change: global and regional perspectives. Hydrological Sciences Journal, 59(1), 128. https://doi.org/10.1080/02626667.2013.857411 
Mafaranga, H. (2020). Heavy Rains, Human Activity, and Rising Waters at Lake Victoria. Eos, 101. https://doi.org/10.1029/2020EO146582

Marthews, T. R., Jones, R. G., Dadson, S. J., Otto, F. E. L., Mitchell, D., Guillod, B. P., \& Allen, M. R. (2019). The Impact of Human-Induced Climate Change on Regional Drought in the Horn of Africa. Journal of Geophysical Research: Atmospheres, 124(8), 4549-4566. https://doi.org/10.1029/2018JD030085

Ngecu, W. M., \& Mathu, E. M. (1999). The El-Nino-triggered landslides and their socioeconomic impact on Kenya. Environmental Geology, 38(4), 277-284. https://doi.org/10.1007/s002540050425

Ngoma, H., Wen, W., Ayugi, B., Babaousmail, H., Karim, R., \& Ongoma, V. (2021). Evaluation of precipitation simulations in $<\mathrm{scp}>\mathrm{CMIP} 6</ \mathrm{scp}>$ models over Uganda. International Journal of Climatology, joc.7098. https://doi.org/10.1002/joc.7098

Nicholson, S. E. (2014). A detailed look at the recent drought situation in the Greater Horn of Africa. Journal of Arid Environments, 103, 71-79. https://doi.org/10.1016/j.jaridenv.2013.12.003

Nicholson, S. E. (2017). Climate and climatic variability of rainfall over eastern Africa. Reviews of Geophysics, 55(3), 590-635. https://doi.org/10.1002/2016RG000544

Nile Basin Initiative (2020). Unprecedented rise in water levels of Lake Victoria. The Nile Basin Initiative. http://bit.ly/35nVqnE

Njiru, M., Kazungu, J., Ngugi, C. C., Gichuki, J., \& Muhoozi, L. (2008). An overview of the current status of Lake Victoria fishery: Opportunities, challenges and management strategies. Lakes \& Reservoirs: Research \& Management, 13(1), 1-12. https://doi.org/10.1111/j.1440-1770.2007.00358.x

Odada, E. O., Olago, D. O., Kulindwa, K., Ntiba, M., \& Wandiga, S. (2004). Mitigation of environmental problems in Lake Victoria, East Africa: causal chain and policy options analyses. Ambio, 33(1-2), 13-23. http://www.ncbi.nlm.nih.gov/pubmed/15083646

Ogega, O. M., Gyampoh, B. A., \& Mistry, M. N. (2020). Intraseasonal Precipitation Variability over West Africa under $1.5^{\circ} \mathrm{C}$ and $2.0^{\circ} \mathrm{C}$ Global Warming Scenarios: Results from CORDEX RCMs. Climate, 8(12), 143. https://doi.org/10.3390/cli8120143

Ogega, O. M., Koske, J., Kung’u, J. B., Scoccimarro, E., Endris, H. S., \& Mistry, M. N. (2020). Heavy precipitation events over East Africa in a changing climate: results from CORDEX RCMs. Climate Dynamics, 55(3-4), 993-1009. https://doi.org/10.1007/s00382-020-05309-z

Olaka, L. A., Ogutu, J. O., Said, M. Y., \& Oludhe, C. (2019). Projected Climatic and Hydrologic Changes to Lake Victoria Basin Rivers under Three RCP Emission Scenarios for 20152100 and Impacts on the Water Sector. Water, 11(7), 1449. https://doi.org/10.3390/w11071449

Otto, F. E. L., Boyd, E., Jones, R. G., Cornforth, R. J., James, R., Parker, H. R., \& Allen, M. R. (2015). Attribution of extreme weather events in Africa: a preliminary exploration of the science and policy implications. Climatic Change, 132(4), 531-543. https://doi.org/10.1007/s10584-015-1432-0

Ram, E. (2020, June 2). "The water will come back": why Kenya's struggle against flooding is far from over. The Guardian. http://bit.ly/3s4s3At

Scheuerer, M., \& Büermann, L. (2014). Spatially adaptive post-processing of ensemble forecasts for temperature. Journal of the Royal Statistical Society: Series C (Applied Statistics), 63(3), 405-422. https://doi.org/10.1111/rssc.12040

Senay, G. B., Velpuri, N. M., Bohms, S., Demissie, Y., \& Gebremichael, M. (2014). 
Understanding the hydrologic sources and sinks in the Nile Basin using multisource climate and remote sensing data sets. Water Resources Research, 50(11), 8625-8650.

https://doi.org/10.1002/2013WR015231

Shamsudduha, M., Taylor, R. G., Jones, D., Longuevergne, L., Owor, M., \& Tindimugaya, C. (2017). Recent changes in terrestrial water storage in the Upper Nile Basin: an evaluation of commonly used gridded GRACE products. Hydrology and Earth System Sciences, 21(9), 4533-4549. https://doi.org/10.5194/hess-21-4533-2017

Smith, K. A., \& Semazzi, F. H. M. (2014). The Role of the Dominant Modes of Precipitation Variability over Eastern Africa in Modulating the Hydrology of Lake Victoria. Advances in Meteorology, 2014, 1-11. https://doi.org/10.1155/2014/516762

Song, X.-P., Hansen, M. C., Stehman, S. V., Potapov, P. V., Tyukavina, A., Vermote, E. F., \& Townshend, J. R. (2018). Global land change from 1982 to 2016. Nature, 560(7720), 639643. https://doi.org/10.1038/s41586-018-0411-9

Stager, J. C., Ruzmaikin, A., Conway, D., Verburg, P., \& Mason, P. J. (2007). Sunspots, El Niño, and the levels of Lake Victoria, East Africa. Journal of Geophysical Research, 112(D15), D15106. https://doi.org/10.1029/2006JD008362

Stehfest, E., van Zeist, W.-J., Valin, H., Havlik, P., Popp, A., Kyle, P., Tabeau, A., MasonD’Croz, D., Hasegawa, T., Bodirsky, B. L., Calvin, K., Doelman, J. C., Fujimori, S., Humpenöder, F., Lotze-Campen, H., van Meijl, H., \& Wiebe, K. (2019). Key determinants of global land-use projections. Nature Communications, 10(1), 2166.

https://doi.org/10.1038/s41467-019-09945-w

Stott, P. A., Stone, D. A., \& Allen, M. R. (2004). Human contribution to the European heatwave of 2003. Nature, 432(7017), 610-614. https://doi.org/10.1038/nature03089

Sutcliffe, J. V., \& Parks, Y. P. (1999). The hydrology of the Nile. The Hydrology of the Nile. IAHS Special Publication No.5., 5(5).

Sutcliffe, John V. (2009). The Hydrology of the Nile Basin (pp. 335-364). https://doi.org/10.1007/978-1-4020-9726-3_17

Sutcliffe, J. V, \& Petersen, G. (2007). Lake Victoria: derivation of a corrected natural water level series / Lac Victoria: dérivation d'une série naturelle corrigée des niveaux d'eau. Hydrological Sciences Journal, 52(6), 1316-1321. https://doi.org/10.1623/hysj.52.6.1316

Swenson, S., \& Wahr, J. (2009). Monitoring the water balance of Lake Victoria, East Africa, from space. Journal of Hydrology, 370(1-4), 163-176.

https://doi.org/10.1016/j.jhydrol.2009.03.008

Thiery, W., Davin, E. L., Panitz, H.-J., Demuzere, M., Lhermitte, S., \& van Lipzig, N. (2015). The Impact of the African Great Lakes on the Regional Climate. Journal of Climate, 28(10), 4061-4085. https://doi.org/10.1175/JCLI-D-14-00565.1

Thiery, W., Davin, E. L., Seneviratne, S. I., Bedka, K., Lhermitte, S., \& van Lipzig, N. P. M. (2016). Hazardous thunderstorm intensification over Lake Victoria. Nature Communications, 7(1), 12786. https://doi.org/10.1038/ncomms12786

Uhe, P., Philip, S., Kew, S., Shah, K., Kimutai, J., Mwangi, E., van Oldenborgh, G. J., Singh, R., Arrighi, J., Jjemba, E., Cullen, H., \& Otto, F. (2018). Attributing drivers of the 2016 Kenyan drought. International Journal of Climatology, 38, e554-e568.

https://doi.org/10.1002/joc.5389

UNEP (2006). Lake Victoria Basin Environment Outlook: Environment and Development. https://bit.ly/3kXwiKV

van der Wiel, K., Kapnick, S. B., van Oldenborgh, G. J., Whan, K., Philip, S., Vecchi, G. A., 
Singh, R. K., Arrighi, J., \& Cullen, H. (2017). Rapid attribution of the August 2016 floodinducing extreme precipitation in south Louisiana to climate change. Hydrology and Earth System Sciences, 21(2), 897-921. https://doi.org/10.5194/hess-21-897-2017

van Oldenborgh, G. J., van der Wiel, K., Sebastian, A., Singh, R., Arrighi, J., Otto, F., Haustein, K., Li, S., Vecchi, G., \& Cullen, H. (2017). Attribution of extreme rainfall from Hurricane Harvey, August 2017. Environmental Research Letters, 12(12), 124009.

https://doi.org/10.1088/1748-9326/aa9ef2

Vanderkelen, I., van Lipzig, N. P. M., \& Thiery, W. (2018a). Modelling the water balance of Lake Victoria (East Africa) - Part 1: Observational analysis. Hydrology and Earth System Sciences, 22(10), 5509-5525. https://doi.org/10.5194/hess-22-5509-2018

Vanderkelen, I., van Lipzig, N. P. M., \& Thiery, W. (2018b). Modelling the water balance of Lake Victoria (East Africa) - Part 2: Future projections. Hydrology and Earth System Sciences, 22(10), 5527-5549. https://doi.org/10.5194/hess-22-5527-2018

Vanem, E. (2015). Uncertainties in extreme value modelling of wave data in a climate change perspective. Journal of Ocean Engineering and Marine Energy, 1(4), 339-359. https://doi.org/10.1007/s40722-015-0025-3

Vermote, E., \& NOAA CDR Program. (2019). NOAA Climate Data Record (CDR) of AVHRR Normalized Difference Vegetation Index (NDVI), Version 5. https://doi.org/https://doi.org/10.7289/V5ZG6QH9

Waiswa, D., Stern, M. J., \& Prisley, S. P. (2015). Drivers of Deforestation in the Lake Victoria Crescent, Uganda. Journal of Sustainable Forestry, 34(3), 259-275. https://doi.org/10.1080/10549811.2014.1003565

Wakabi, W. (2006). "Worst drought in a decade" leaves Kenya crippled. The Lancet, 367(9514), 891-892. https://doi.org/10.1016/S0140-6736(06)68364-5

Washington, R., Harrison, M., Conway, D., Black, E., Challinor, A., Grimes, D., Jones, R., Morse, A., Kay, G., \& Todd, M. (2006). African Climate Change: Taking the Shorter Route. Bulletin of the American Meteorological Society, 87(10), 1355-1366. https://doi.org/10.1175/BAMS-87-10-1355

Williams, K., Chamberlain, J., Buontempo, C., \& Bain, C. (2015). Regional climate model performance in the Lake Victoria basin. Climate Dynamics, 44(5-6), 1699-1713. https://doi.org/10.1007/s00382-014-2201-X

Willmott, C., \& Matsuura, K. (2005). Advantages of the mean absolute error (MAE) over the root mean square error (RMSE) in assessing average model performance. Climate Research, 30, 79-82. https://doi.org/10.3354/cr030079

World Bank Group (2016). Reviving Lake Victoria by Restoring Livelihoods. https://www.worldbank.org/en/news/feature/2016/02/29/reviving-lake-victoria-byrestoring-livelihoods

Wu, T., Lu, Y., Fang, Y., Xin, X., Li, L., Li, W., Jie, W., Zhang, J., Liu, Y., Zhang, L., Zhang, F., Zhang, Y., Wu, F., Li, J., Chu, M., Wang, Z., Shi, X., Liu, X., Wei, M., ... Liu, X. (2019). The Beijing Climate Center Climate System Model (BCC-CSM): the main progress from CMIP5 to CMIP6. Geoscientific Model Development, 12(4), 1573-1600. https://doi.org/10.5194/gmd-12-1573-2019

Yang, W., Seager, R., Cane, M. A., \& Lyon, B. (2015). The Annual Cycle of East African Precipitation. Journal of Climate, 28(6), 2385-2404. https://doi.org/10.1175/JCLI-D-1400484.1

Yazdandoost, F., Moradian, S., Izadi, A., \& Aghakouchak, A. (2021). Evaluation of CMIP6 
precipitation simulations across different climatic zones: Uncertainty and model intercomparison. Atmospheric Research, 250, 105369.

https://doi.org/10.1016/j.atmosres.2020.105369

Zhang, W., Villarini, G., Scoccimarro, E., \& Vecchi, G. A. (2017). Stronger influences of increased CO 2 on subdaily precipitation extremes than at the daily scale. Geophysical Research Letters, 44(14), 7464-7471. https://doi.org/10.1002/2017GL074024

Zhang, X., Alexander, L., Hegerl, G. C., Jones, P., Tank, A. K., Peterson, T. C., Trewin, B., \& Zwiers, F. W. (2011). Indices for monitoring changes in extremes based on daily temperature and precipitation data. WIREs Climate Change, 2(6), 851-870. https://doi.org/10.1002/wcc.147

Zhou, R.-G., Hu, W., Fan, P., \& Ian, H. (2017). Quantum realization of the bilinear interpolation method for NEQR. Scientific Reports, 7(1), 2511. https://doi.org/10.1038/s41598-01702575-6 